\title{
Detection of Class 1 Integron Encoding Gene in Multidrug Resistance (MDR) Citrobacter freundii Isolated from Healthy Broiler Chicken
}

\author{
A. M. Witaningrum ${ }^{a}$, F. J. Wibisono ${ }^{\text {b }}$, D. A. Permatasari ${ }^{a}$, \& M. H. Effendi ${ }^{a}$,* \\ aDepartment of Veterinary Public Health, Faculty of Veterinary Medicine, Universitas Airlangga \\ ${ }^{b}$ Department of Veterinary Public Health, Faculty of Veterinary Medicine, Universitas Wijaya Kusuma, Surabaya \\ Jalan Kampus C Mulyorejo, FKH UNAIR, Surabaya 60115, Indonesia \\ ${ }^{*}$ Corresponding author: mheffendi@yahoo.com \\ (Received 01-09-2020; Revised 18-01-2021; Accepted 16-02-2021)
}

\begin{abstract}
This study was aimed to find out that broiler chicken farms have problems with antibiotic resistance Citrobacter freundii and determined the prevalence and class 1 integron encoding gene. Multidrug resistance Citrobacter freundii was collected from broiler chicken among one hundred and sixty cloacal swab samples from 32 farms in Blitar for 3 months. The method of bacterial inoculation used MacConkey agar and biochemical test was conducted by IMViC and TSIA test. Citrobacter freundii for antibiotic sensitivity pattern was tested by disk diffusion, and the multidrug resistance encoding gene was tested by PCR. This study exposed 160 samples, and $13.75 \%$ (22/160) samples were positive of Citrobacter freundii. The antibiotic sensitivity pattern showed high resistances against ampicillin and erythromycin $(77.27 \%)$, tetracycline $(59.09 \%)$, trimetropim-sulfamethoxazole $(50 \%)$, and streptomycin $(22.72 \%)$. Isolates that were detected as multidrug resistance were continued with PCR testing to prove the existence of a class 1 integron encoding gene. Multidrug resistance Citrobacter freundii isolated from broiler chicken farms in Blitar were $81.82 \%(18 / 22)$, and were indicated that five were positive Class 1 Integron encoding gene. The results of this study showed that the prevalence and distribution of multidrug resistance Citrobacter freundii were high, so it can cause the spread of antimicrobial resistance to public health. Class 1 integron encoding gene was found $22.72 \%$ from multidrug resistance Citrobacter freundii by PCR. It was concluded that broiler chicken farms need assessment management to reduce and avoid multidrug resistance bacteria in animals and human. Therefore, the use of appropriate antibiotics is a good step to reduce the incidence of MDR in poultry.
\end{abstract}

Keywords: broiler chicken; Citrobacter freundii; Class 1 integron encoding gene; multidrug resistance; public health

\section{INTRODUCTION}

Antibiotic is commonly used to prevent bacteria infection in poultry (Mehdi et al., 2018). Poultry management applied more than one antibiotic to control bacteria (Roth et al., 2019). Multi antibiotics uses for treatment caused resistance to bacteria and became a global public health problem (Prestinaci et al., 2015). Antibiotics have been used for the treatment and prevention of disease in animals. Food of animal origin contains large amounts of antibiotic residues due to high antibiotic treatment, and this residue can be transmitted from animal products to humans (Landers et al., 2012). Antibiotic resistance was found and detected at the Class 1 integrons encoding gene in poultry (Asgharpour et al., 2018).

Integrons are gene to express encoding for antibiotic resistance (Kheiri et al, 2016). Integrons are discovered on the transposons and contain inserted gene cassettes. The characterization of integrons is to harbor gene cassettes coding for resistance to antimicrobial (Domingues et al., 2012; Permatasari et al., 2020). Class 1 integrons are frequently reported with high prevalence in Gram negative bacteria, including Citrobacter freundii. The class 1 integrons are found to be pathogen and made a worldwide significant bacterial infection in livestock (Karimi et al., 2020; Hidayatullah et al., 2020).

Enterobacteriaceae is frequently found in poultry (Projahn et al., 2018), especially Citrobacter freundii. Citrobacter freundii is Gram negative, coccobacilli, motile using flagella and facultative anaerobic bacteria and commonly found in food, soil, water, and the intestines of animals and humans (Liu et al., 2018). Citrobacter freundii existed in gastrointestinal and distributed food borne diseases of animals (Bai et al., 2012; Prota et al., 2015). Antibiotics inhibited the growth of bacteria, and treatment of multiple drugs caused resistance in bacteria infection. Multidrug resistance has been the global public problem (Liu et al., 2018; Ansharieta et al., 2020). Therefore, a detection method is needed at the molecular level to prove the spread of multidrug resistance (MDR) in poultry farms. The use of the Class 1 integron gene coding for the detection of MDR in $C$. fruendii on poultry is a new step in the right direction. 
This study was designed to evaluate the class 1 integron in broiler poultry farms and assessment of the multidrug resistance encoding gene amongst Citrobacter freundii. This study was designed to determine the possibility of emerge multidrug resistance caused by class 1 integron from bacteria in poultry farms.

\section{MATERIALS AND METHODS}

\section{Ethical Clearance}

Cloacal swabs were used in this study. Hence ethical clearance was not necessary. Cloacal swabs were collected from broiler chicken farms in Blitar, East Java province, Indonesia.

\section{Sample Isolation and Identification}

This cross-sectional study was conducted between June and August 2019. One hundred and sixty cloacal swab samples were collected from broiler chicken farms in Blitar, Indonesia. The Sampling of the farm was based on less maintenance, sanitation, cleanliness, and hygiene management (Effendi et al., 2018). The cloacal swab samples were cultured and incubated in MacConkey agar plates (Oxoid, Cheshire, UK) at $37^{\circ} \mathrm{C}$ for $24 \mathrm{~h}$ (Al Humam, 2016). The positive of Citrobacter freundii were indicated by lactose fermenting in MacConkey agar and colonies of bacteria obtain acquire pure subcultures (Liu et al., 2017). Colonies of Citrobacter freundii were confirmed by biochemistry test. Indol test, Simmon Citrate Agar and TSIA were biochemistry tests to identify genus and species of Citrobacter freundii (Janda et al., 1994; Nayar et al., 2014).

\section{Antibiotic Sensitivity Test}

Kirby-Bauer disc diffusion assay on medium Mueller-Hilton agar was done for testing antibiotic sensitivity (Nassar et al., 2019; Effendi et al., 2019). Erythromycin $15 \mu \mathrm{g}$, streptomycin $(10 \mu \mathrm{g})$, tetracycline (30 $\mu \mathrm{g})$, trimethoprim-sulfamethoxazole $(25 \mu \mathrm{g})$, and ampicillin $(10 \mu \mathrm{g})$ were antibiotics used to represent the antibiotic resistance according to Clinical and Laboratory Standards Institute recommendation. Antimicrobial susceptibility testing was carried out by measurement of inhibitory zone diameter formed at $3^{\circ} \mathrm{C}$ for 24 hours. (Clinical and Laboratory Standards Institute, 2017).

\section{Detection of Class 1 Integron Encoding Gene}

Citrobacter freundii was revealed multidrug resistance using PCR method and analysis subtypes Class I Integron encoding gene identification. DNA isolation was done with the QIAamp® DNA mini kit (QIAGEN, Germany). The primers encoding the gene Class 1 Integron were hep 58 (TCATGGCTTGTTATGACTGT) and hep 59 (GTAGGGCTTATTATGCACGC). We used GoTaq Green mastermix (Promega, USA) and PCR condition with denaturation temperatures for 2 minutes at $94^{\circ} \mathrm{C}$; extended denaturation at $94^{\circ} \mathrm{C}$ for 30 seconds; annealing at $55^{\circ} \mathrm{C}$ for 45 seconds; extension at $72^{\circ} \mathrm{C}$ for 45 seconds; final extension at $72^{\circ} \mathrm{C}$ for 7 minutes, this reaction is carried out for 30 cycles. PCR results were confirmed by electrophoresis using $2 \%$ agarose gel (Invitrogen, USA), the amplicon using primer hep 58 and hep 59 was $200 \mathrm{bp}$ (Singh et al., 2017).

\section{RESULTS}

Cloacal swab samples were collected from 160 chickens in broiler poultry farms in Blitar and the appearance of multidrug resistance (MDR) Citrobacter freundii was detected. The sample was obtained 13.75\% (22/160) Citrobacter freundii and $81.82 \%$ (18/22) multidrug resistance cases in broiler poultry farms.

The antibiotic sensitivity test showed that the highest multidrug resistance Citrobacter freundii to ampicillin and erythromycin (77.27\%), tetracycline (59.09\%), trimetropim-sulfamethoxazole (50.00\%), and streptomycin $(22.72 \%)$ (Table 1$)$. The most multidrug resistance showing sensitive to antibiotic is streptomycin $(77.27 \%)$. Antibiotics are commonly used to affect sensitive bacteria, but if used inappropriately, they can lead to antibiotic resistance (Singh et al., 2017).

The amplification Class 1 Integron of Citrobacter freundii from 22 cloacal swab samples of broiler poultry was positive for $200 \mathrm{bp}$ using the primer hep 58 and hep 59 (Nagachinta et al., 2009). The results indicated that five were positive Class 1 Integron encoding genes (Table 2).

The results showed that several resistance antibiotics of Citrobacter freundii are related to the appearance of the Class 1 Integron. Figure 1 shows Citrobacter freundii are resistance to several antibiotics. Figure 2 shows that multidrug resistance to antibiotics. The multidrug resistance Citrobacter freundii by antibiotic susceptibility testing was confirmed 18/22 (81.82\%), and Class 1 Integron encoding gene positive by PCR testing was showed 5/22 (22.72\%) (Figure 3).

\section{DISCUSSION}

The study discovered contamination of Citrobacter freundii caused pathogen and foodborne diseases in broiler farms (Aminharati et al., 2019). The multidrug resistance to several antibiotics was reported from isolated 160 cloacal swab samples. The major public health problem has many cases especially higher prevalence of

Table 1. Antibiotic susceptibility profile of Citrobacter freundii in broiler chicken farms in Blitar, Indonesia

\begin{tabular}{lccc}
\hline Antibiotics & $\begin{array}{c}\text { Resistance } \\
(\%)\end{array}$ & $\begin{array}{c}\text { Intermediate } \\
(\%)\end{array}$ & $\begin{array}{c}\text { Sensitive } \\
(\%)\end{array}$ \\
\hline Ampicillin (AMP) & $17(77.27 \%)$ & $1(4.55 \%)$ & $4(18.18 \%)$ \\
Erythromycin (E) & $17(77.27 \%)$ & $3(13.64 \%)$ & $2(9.09 \%)$ \\
Tetracycline (TE) & $13(59.09 \%)$ & 0 & $9(40.91 \%)$ \\
Trimethrophim- & $11(50.00 \%)$ & 0 & $11(50.00 \%)$ \\
sulfamethoxazole & & & \\
(SXT) & & & $17(77.27 \%)$ \\
Streptomycin (S) & $5(22.73 \%)$ & 0 & \\
\hline
\end{tabular}


Table 2. Samples result of multidrug resistant (MDR) and Class 1 Integron cases on Citrobacter freundii

\begin{tabular}{|c|c|c|c|c|}
\hline Locations & $\begin{array}{l}\text { Sample of Citrobacter } \\
\text { freundii }\end{array}$ & $\begin{array}{c}\text { Positive Citrobacter } \\
\text { freundii }\end{array}$ & Positive MDR & $\begin{array}{c}\text { Positive Class } 1 \text { Integron } \\
\text { by PCR }\end{array}$ \\
\hline Farm 3 & B3an, B3bn, B3cn & $3(13.64 \%)$ & $2(9.09 \%)$ & $1(4.55 \%)$ \\
\hline Farm 4 & B4bn, B4dn & $2(9.09 \%)$ & 0 & 0 \\
\hline Farm 7 & B7cn & $1(4.55 \%)$ & $1(4.55 \%)$ & 0 \\
\hline Farm 8 & B8an, B8en & $2(9.09 \%)$ & $2(9.09 \%)$ & 0 \\
\hline Farm 11 & B11en & $1(4.55 \%)$ & $1(4.55 \%)$ & $1(4.55 \%)$ \\
\hline Farm 14 & B14an, B14bn & $2(9.09 \%)$ & $2(9.09 \%)$ & $2(9.09 \%)$ \\
\hline Farm 26 & B26bn & $1(4.55 \%)$ & $1(4.55 \%)$ & 0 \\
\hline Farm 27 & B27an, B27en & $2(9.09 \%)$ & $2(9.09 \%)$ & 0 \\
\hline Farm 28 & B28cn, B28dn & $2(9.09 \%)$ & $1(4.55 \%)$ & 0 \\
\hline Farm 30 & B30an, B30dn, B30en & $3(13.64 \%)$ & $3(13.64 \%)$ & 0 \\
\hline Farm 31 & B31an, B31cn, B31en & $3(13.64 \%)$ & $3(13.64 \%)$ & $1(4.55 \%)$ \\
\hline
\end{tabular}

Note: Bold code= positive result of MDR Citrobacter freundii; Italic code= positive result of Class 1 Integron gene.

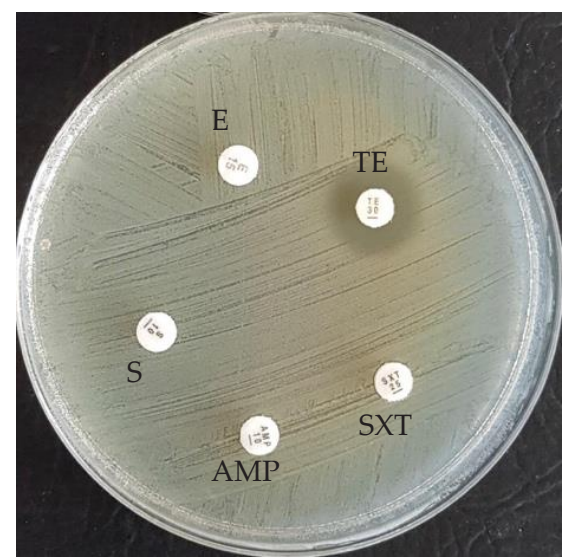

Figure 1. Antibiotic susceptibility profile of Citrobacter freundii from broiler chicken farms in Blitar, Indonesia with result was multidrug resistant (MDR). The antibiotic were Ampicillin (AMP), Erytrhromycin (E), Tetracycline (TE), Trimethrophim-sulfamethoxazole (SXT), and Streptomycyn (S). The samples were incubated at $37^{\circ} \mathrm{C}$ for 24 hours.

Note: AMP, E, SXT, and S were resistant to Citrobacter freundii; TE was sensitive. Therefore, this isolate was MDR due to more than three antibiotics resistant.

multidrug resistant bacterial pathogens. Integrons are related to multidrug resistance in many cases of bacterial diseases (Akrami et al., 2019; Krauland et al., 2009). Integrons were recognized and detected first time in Gram-negative bacteria (Deng et al., 2015; Domingues et al., 2012; Pormohammad et al., 2019).

Organisms that are resistant to three or more classes of antimicrobials are referred to as multidrug resistant (MDR) (Magiorakos et al., 2012; Wibisono et al., 2020). One method frequently used by various researchers to characterize organisms as MDR is based on the results of in vitro antimicrobial susceptibility testing (Kallen et al., 2010). The most commonly used definition is for Gram-negative bacteria that are resistant to three or more classes of antimicrobials (Gould, 2008, Kristianingtyas et al., 2020). The variability of this definition is provided in the comprehensive MDR review

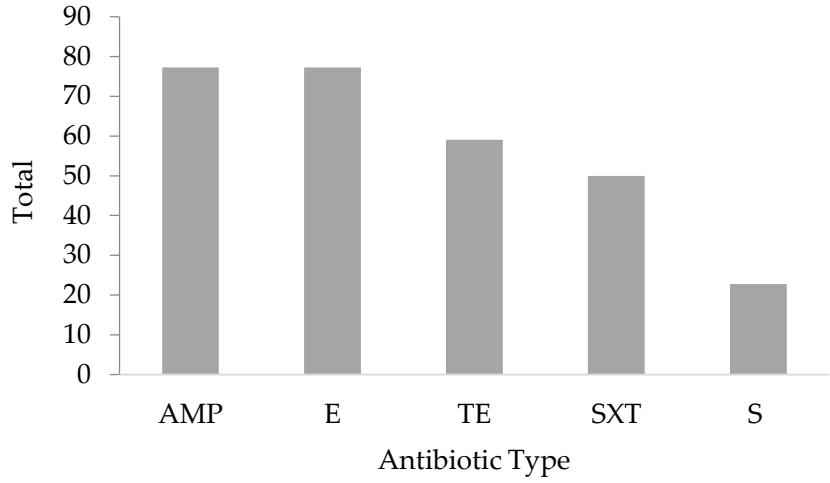

Figure 2. Precentage of antibiotic resistance on Citrobacter freundii. AMP (Ampicillin), E (Erytrhromycin), TE (Tetracycline), SXT (Trimethrophim-sulfamethoxazole), and S (Streptomycyn).

(Falagas et al., 2006), which is used by some researchers as a reference that a large number of studies do not propose a specific definition for MDR.

There were 18 MDR of Citrobacter freundii isolates in this study, shown in Table 2, although 5 isolates contain Class 1 integrons gene of Citrobacter freundii in this study. Other isolates are shown negative of Class 1 integrons gene because globally pathogens of Class 1 integrons discovered on the chromosomes of environmental bacteria. Four classes of integron have been described, each of which codes for a distinct but related integrase enzyme. Class 1 integrons are the most widely studied (Rosser \& Young, 1999). Class 1 integrons are bounding in conjugative plasmids, transposons conjugative plasmids, and spreading by lateral gene transfer. Therefore, Class 1 integrons have overspread to almost all species of Gramnegative pathogens. Class 1 integron is a major competence in the global spread of multidrug resistance and important to recover management of the farm to decrease the prevalence of antibiotic resistance and improving the balance of healthy life.

Consumption of antibiotics increased antibiotic resistance containing important MDR organisms in poultry. These MDR organisms can be transmitted to humans 


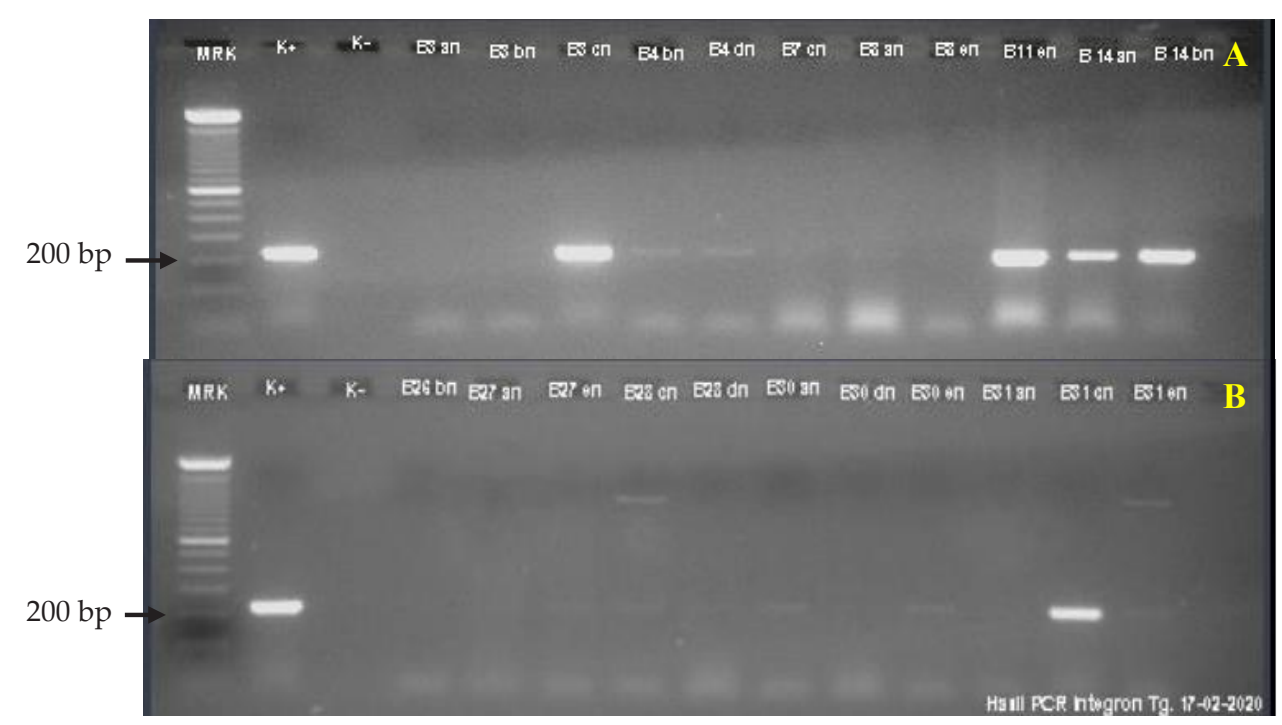

Figure 3. Class 1 Integron gene of Citrobacter freundii from broiler chicken farms in Blitar, Indonesia. MRK (marker), $\mathrm{K}+$ (positive control) was used Escherichia coli from patients of multidrug resistance (MDR), K- (negative control) was used Pseudomonas aeruginosa ATCC 27853. A) B3cn, B11en, B14an, B14bn were positive result of Class 1 Integron; B) B31cn was positive result of Class 1 Integron.

through direct contact or consumption, and C. freundii causes economic losses and levels of food contamination. Therefore antibiotic-resistant genes have the potential to spread to other populations. The abundant use of antibiotics in poultry farming has been linked to treatment failure and the development of antibiotic resistance itself.

Integrons are genes encoding multidrug resistance and reduction of treatment for bacterial infections (Mostafa et al., 2015). The classification of integrons is based on differences in the gene structure of integrases (Cury et al., 2015). The spread of Class 1 integrons have been found commonly in Gram-negative bacteria and showed the existence of Class 1 integrons of Citrobacter freundii in this study. The appearance result of amplification class 1 integron from positive isolates were $22.72 \%$. The amplification using primer hep 58 and hep 59 for 200bp represent class 1 integron of Citrobacter freundii. Multidrug resistance was reported to be spread by Class 1 integron genes in Gram-negative bacteria.

The multidrug resistance nature of this isolate can be explained by the fact that it is mediated by plasmids carrying multiresistant genes and by transposons, and by integrons that are easily transferred to other bacteria, not necessarily of the same species (Widodo et al., 2020). Bacteria with various resistance to antibiotics are widespread in animals and the environment (Kwoji et al., 2019, Riwu et al., 2020). Recent surveys from China (Gao et al., 2015), Thailand (Runcharoen et al., 2017), and Indonesia (Effendi et al., 2018), have illustrated an alarming trend regarding resistance among broad-spectrum beta lactamase-producing organisms (ESBLs), which are also multidrug-resistant isolated from animals and the environment (Wibisono et al., 2020).

Farm animals are frequently found to be infected by pathogenic bacteria and the infection can be transfered from animals to humans, especially Citrobacter freundii (Zhou et al., 2019; Liu et al., 2017). The treatment to pathogenic bacteria used large amounts of antibiotics to reduce attack infection and caused resistance to multiple drugs. Multidrug resistance bacteria are most important to observation concern because influence public health problem.

\section{CONCLUSION}

Citrobacter freundii was discovered in broiler chicken. This study showed that multidrug resistance Citrobacter freundii was confirmed 18/22 (81.82\%), and Class 1 Integron encoding gene positive by PCR testing was $5 / 22(22.72 \%)$. The result revealed multidrug resistance Gram negative bacteria emerge in poultry farms and need evaluation management plans to prevent the transfer of multidrug resistance bacteria from poultry to humans and the environment.

\section{CONFLICT OF INTEREST}

The authors declare that there is no conflict of interest with any financial, personal, or other relationships with other people or organization related to the material discussed in the manuscript.

\section{ACKNOWLEDGEMENT}

This research was in part funded by the Direktorat Riset dan Pengabdian Masyarakat, Deputi Bidang Penguatan Riset dan Pengembangan Kementerian Riset dan Teknologi/ Badan Riset dan Inovasi Nasional, Indonesia in fiscal year 2020 with grant number: 756/ UN3.14/PT/2020.

\section{REFERENCES}

Akrami, F., M. Rajabnia, \& A. Pournajaf. 2019. Resistance integrons; A mini review. Caspian J. Intern. Med. 10:370-376. 
Aminharati, F., M. H. Ehrampoush, S. M. Dallal, S. M., M. Yaseri, D. A. Tafti, \& Z. Rajabi. 2019. Citrobacter freundii Foodborne disease outbreak related to environmental conditions in Yazd Province, Iran. Iran J. Public Health. 48:1099-1105. https://doi.org/10.18502/ijph.v48i6.2919

Ansharieta, R., M. H. Effendi, \& H. Plumeriastuti. 2020. Detection of multidrug-resistant (MDR) Escherichia coli isolated from raw milk in East Java Province, Indonesia. Indian J. Forensic Med. Toxicol. 14:4303-4307

Asgharpour, F., S. Mahmoud, A. Marashi, \& Z. Moulana. 2018. Molecular detection of class 1, 2 and 3 integrons and some antimicrobial resistance genes in Salmonella infantis isolates. Iran J. Microbiol. 10:104-110.

Bai, L., S. Xia, R. Lan, L. Liu, C. Ye, Y. Wang, D. Jin, Z. Cui, H. Jing, Y. Xiong, X. Bai, H. Sun, J. Zhang, L. Wang, \& J. Xu. 2012. Isolation and characterization of cytotoxic, aggregative Citrobacter freundii. PLoS ONE 7:e33054. https://doi. org/10.1371/journal.pone.0033054

Clinical and Laboratory Standarts Institute. 2017. Performances Standards for Antimicrobial Susceptibility Testing. 27 $7^{\text {th }}$ ed. CLSI supplement M100. Clinical and Laboratory Standards Institute, Wayne.

Cury, J., T. Jové, , M. Touchon, B. Néron, \& E. P. Rocha. 2016. Identification and analysis of integrons and cassette arrays in bacterial genomes. Nucleic Acids Res. 44:4539-4550. https://doi.org/10.1093/nar/gkw319

Dehkordi, M. K., M. Halaji, \& S. Nouri. 2020. Prevalence of class 1 integron in Escherichia coli isolated from animal sources in Iran: a systematic review and meta-analysis. Trop. Med. Health. 48:1-7. https://doi.org/10.1186/s41182-020-00202-1

Deng, Y., X. Bao, L. Ji, L. Chen, J. Liu, J. Miao, D. Chen, H. Bian, Y. Li, \& G. Yu. 2015. Resistance integrons: class 1, 2 and 3 integrons. Ann. Clin. Microbiol. Antimicrob. 14:1-11. https://doi.org/10.1186/s12941-015-0100-6

Domingues, S., G. J. da Silva, \& K. M. Nielsen. 2012. Integrons: Vehicles and pathways for horizontal dissemination in bacteria. Mobile genetic elements 2:211-223. https://doi. org/10.4161/mge.22967

Effendi, M. H., I.G. Bintari, E. B. Aksono, \& I. P. Hermawan. 2018. Detection of blaTEM gene of Klebsiella pneumoniae isolated from swab of food-producing animals in East Java. Trop. Anim. Sci. J. 41:174-178. https://doi.org/10.5398/ tasj.2018.41.3.174

Effendi M.H., N. Harijani, S. M. Yanestria \& P. Hastutiek. 2018. Identification of shiga toxin-producing Escherichia coli in raw milk samples from dairy cows in Surabaya, Indonesia. Philipp. J. Ved. Med. 55:109-114.

Effendi, M.H., N. Harijani, Budiarto, N. P. Triningtya, W. Tyasningsih, \& H. Plumeriastuti. 2019. Prevalence of pathogenic Escherichia coli Isolated from Subclinical Mastitis in East Java Province, Indonesia. Indian Vet. J. 96:22-25. https://doi.org/10.13057/biodiv/d220137

Falagas, M. E., P. K. Koletsi, \& I. A. Bliziotis. 2006. The diversity of definitions of multidrug-resistant (MDR) and pandrugresistant (PDR) Acinetobacter baumannii and Pseudomonas aeruginosa. J. Med. Microbiol. 55:1619-1629. https://doi. org/10.1099/jmm.0.46747-0

Gould, I. M. 2008. The epidemiology of antibiotic resistance. Int. J. Antimicrob. Agents. 32 (suppl 1): 2-9. https://doi. org/10.1016/j.ijantimicag.2008.06.016

Hidayatullah, A. R., M. H. Effendi, H. Plumeriastuti, F. M. Wibisono, E.B. Hartadi, \& E. D. Sofiana. 2020. A Review of the opportunistic pathogen Citrobacter freundii in piglets post weaning : Public Health Importance. Sys. Rev. Pharm. 11:767-773.

Humam, N. A. 2016. Special biochemical profiles of Escherichia coli strains isolated from humans and camels by the VITEK 2 automated system in Al-Ahsa, Saudi Arabia.
Afr. J. Microbiol. Res.10: 783-790. https://doi.org/10.5897/ AJMR2016.8047

Janda, J. M., S. L. Abbott, W. K. W. Cheung, \& D. F Hanson. 1994. Biochemical identification of Citrobacteria in the clinical laboratory. J. Clin. Microbiol. 32: 1850-1854. https://doi. org/10.1128/JCM.32.8.1850-1854.1994

Kallen, A. J., A. I. Hidron, J. Patel, \& A. Srinivasan. 2010. Multidrug resistance among gram-negative pathogens that caused healthcare-associated infections reported to the National Healthcare Safety Network, 2006-2008. Infect. Control Hosp. Epidemiol. 31:528-531. https://doi. org/10.1086/652152

Kheiri, R. \& L. Akhtari. 2016. Antimicrobial resistance and integron gene cassette arrays in commensal Escherichia coli from human and animal sources in IRI. Gut pathog. 8:1-10. https://doi.org/10.1186/s13099-016-0123-3

Krauland, M. G., J. W. Marsh, D. L. Paterson, \& L. H. Harrison. 2009. Integron-mediated multidrug resistance in a global collection of nontyphoidal Salmonella enterica isolates. Emerg. Infect. Dis. 15:388-396. https://doi.org/10.3201/ eid1503.081131

Kristianingtyas, L., M. H. Effendi, W. Tyasningsih, \& F. Kurniawan. 2020. Genetic identification of blactx-M gene and blatem gene on Extended Spectrum Beta Lactamase (ESBL) producing Escherichia coli from dogs. Indian Vet. J. 97:17-21

Kwoji, I. D., J. A. Musa, N. Daniel, D. L. Mohzo, A. A. Bitrus, A. A. Ojo, \& K. U. Ezema. 2019. Extended-spectrum beta-lactamase-producing Escherichia coli in chickens from smallscale (backyard) poultry farms in Maiduguri, Nigeria. Int. J. One Health. 5:26-30. https://doi.org/10.14202/ IJOH.2019.26-30

Landers, T. F., B. Cohen, T. E. Wittum, \& E. L. Larson. 2012. A review of antibiotic use in food animals: perspective, policy, and potential. Public Health Rep. 127:4-22. https:// doi.org/10.1177/003335491212700103

Liu, L., D. Chen, L. Liu, R. Lan, S. Hao, W. Jin, H. Sun, Y. Wang, Y. Liang, \& J. Xu. 2018. Genetic diversity, multidrug resistance, and virulence of Citrobacter freundii from diarrheal patients and healthy individuals. Front. Cell. Infect. Microbiol. 8:1-10 https://doi.org/10.3389/fcimb.2018.00233

Liu, L. H., N. Y. Wang, A. Y. J. Wu, C. C. Lin, C. M. Lee, \& C. P. Liu. 2018. Citrobacter freundii bacteremia: Risk factors of mortality and prevalence of resistance genes. J. Microbiol. Immunol. Infect. 51:565-572. https://doi.org/10.1016/j. jmii.2016.08.016

Liu, L., R. Lan, L. Liu, Y. Wang, Y. Zhang, Y. Wang, \& J. Xu. 2017. Antimicrobial resistance and cytotoxicity of Citrobacter spp. in Maanshan Anhui Province, China. Front. Microbiol. 8:1357. https://doi.org/10.3389/fmicb.2017.01357

Magiorakos, A.P., A. Srinivasan, R. B. Carey, Y. Carmeli, M. E. Falagas, C. G. Giske, S. Harbarth, J. F. Hindler, G. Kahlmeter, B. O. Liljequist, D. L. Paterson, L. B. Rice, J. Stelling, M. J. Struelens, A. Vatopoulos, J. T. Weber, \& D. L. Monnet. 2012. Multidrug-resistant, extensively drug-resistant and pandrug-resistant bacteria: an international expert proposal for interim standard definitions for acquired resistance. Clin. Microbiol. Infect. 18:268-281. https://doi. org/10.1111/j.1469-0691.2011.03570.x

Mehdi, Y., M. P. L. Montminy, M. L. Gaucher, Y. Chorfi, G. Suresh, T. Rouissi, S. K. Brar, C. Côté, A. A. Ramirez, \& S. Godbout. 2018. Use of antibiotics in broiler production: Global impacts and alternatives. Anim. Nutr. 4:170-178. https://doi.org/10.1016/j.aninu.2018.03.002

Mostafa, M., , S. D. Siadat, F. Shahcheraghi, F. Vaziri, A. J. Nejad, J. V. Yousefi, B. Rajaei, E. H. Mood, N. E. Zadeh, A. Moshiri, S. A. S. Siamdoust, \& M. Rahbar. 2015. Variability in gene cassette patterns of class 1 and 
2 integrons associated with multi drug resistance patterns in Staphylococcus aureus clinical isolates in TehranIran. BMC microbial. 15:152. https://doi.org/10.1186/ s12866-015-0488-3

Nagachinta, S. \& J. Chen. 2009. Integron-mediated antibiotic resistance in Shiga Toxin-producing Escherichia coli. J. Food Prot. 72:21-27. https://doi.org/10.4315/0362-028X-72.1.21

Nassar, M. S. M, W. A. Hazzah, \& W. M. K. Bakr. 2019. Evaluation of antibiotic susceptibility test results: how guilty a laboratory could be?. J. Egypt Public Health Assoc. 94:4. https://doi.org/10.1186/s42506-018-0006-1

Nayar, R., I. Shukla, \& A. Sultan. 2014. Epidemiology, prevalence and identification of Citrobacter species in clinical specimens in a tertiary care hospital in India. International Journal of Scientific and Research Publications 4:4.

Permatasari, D. A., A. M. Witaningrum, F. J. Wibisono, \& M. H. Effendi. 2020. Detection and prevalence of Multidrug Resistant Klebsiella pneumoniae strains isolated from poultry farms in Blitar, Indonesia. Biodiversitas 21:4642-4647. https://doi.org/10.13057/biodiv/d211024

Pormohammad, A., R. Pouriran, H. Azimi, \& M. Goudarzi. 2019. Prevalence of integron classes in Gram-negative clinical isolated bacteria in Iran: A systematic review and meta-analysis. Iran J. Basic Med. Sci. 22:118-127.

Prestinaci, F., P. Pezzotti, \& A. Pantosti. 2015. Antimicrobial resistance: A global multifaceted phenomenon. Pathog. Glob. Health. 109:309-318. https://doi.org/10.1179/2047773 215Y.0000000030

Projahn, M., E. Pacholewicz, E. Becker, G. C. Carreira, N. Bandick, \& A. Kaesbohrer. 2018. Reviewing interventions against Enterobacteriaceae in Broiler processing: Using old techniques for meeting the new challenges of ESBL E. coli?. Biomed Res. Int. 2018:7309346. https://doi. org $/ 10.1155 / 2018 / 7309346$

Prota, M. A., A. P. Sandoval, M. G. Clemente, R. Fernández, \& P. Casan. 2015. Community-acquired pneumonia and empyema caused by Citrobacter koseri in an immunocompetent patient. Case Rep. Pulmonol. 2015:1-6. https://doi. org/10.1155/2015/670373

Riwu, K. H. P., M. H. Effendi, \& F. A. Rantam. 2020. A review of extended Spectrum $\beta$-Lactamase (ESBL) producing Klebsiella pneumoniae and Multidrug Resistant (MDR) on companion animals. Sys. Rev. Pharm. 11:270-277.

Rosser, S. J. \& Young, H. K. 1999. Identification and characterization of class 1 integrons in bacteria from an aquatic environment. J. Antimicrob. Chemother. 44:11-18. https://doi. org/10.1093/jac/44.1.11

Roth, N., A. Käsbohrer, S. Mayrhofer, U. Zitz, C. Hofacre, \& K. J. Domig. 2019. The application of antibiotics in broiler production and the resulting antibiotic resistance in Escherichia coli: A global overview. Poult. Sci. 98:1791-1804. https://doi.org/10.3382/ps/pey539

Runcharoen, C., K. E. Raven, S. Reuter, T. Kallonen, S. Paksanont, \& J. Thammachote. 2017. Whole-genome sequencing of ESBL producing Escherichia coli isolated from patients, farm waste and canals in Thailand. Gen. Med. 9:81-93. https://doi.org/10.1186/s13073-017-0471-8

Singh, T., S. Das, V. G. Ramachandran, S. Wani, D. Shah, K. A. Maroof, \& A. Sharma. 2017. Distribution of integrons and phylogenetic groups among enteropathogenic Escherichia coli isolates from children $<5$ years of age in Delhi, India. Front. Microbiol. 8;561. https://doi.org/10.3389/ fmicb.2017.00561

Wibisono, F. J., B. Sumiarto, T. Untari, M. H. Effendi, D. A. Permatasari, \& A. M. Witaningrum. 2020. The presence of Extended Spectrum Beta-Lactamase (ESBL) producing Escherichia coli on layer chicken farms in Blitar area, Indonesia. Biodiversitas 21: 2667-2671. https://doi. org/10.13057/biodiv/d210638

Wibisono, F.J., B. Sumiarto, , T. Untari, , M.H. Effendi, , D.A. Permatasari, \& A.M. Witaningrum. 2020. Short Communication: Pattern of antibiotic resistance on extended-spectrum beta-lactamases genes producing Escherichia coli on laying hens in Blitar, Indonesia. Biodiversitas 21: 4631-4635. https://doi.org/10.13057/biodiv/d211022

Widodo, A., M. H. Effendi, \& A. R. Khairullah. 2020. Extendedspectrum beta-lactamase (ESBL)-producing Eschericia coli from livestock. Sys. Rev. Phar. 11: 382-392.

Zhou, W., Q. Chen, C. Qian, K. Shen, X. Zhu, D. Zhou, W. Lu, Z. Sun, H. Liu, K. Li, T. Xu, Q. Bao, \& J. Lu. 2019. In Vitro susceptibility and florfenicol resistance in Citrobacter isolates and whole-genome analysis of multidrug-resistant Citrobacter freundii. Int. J. Genomics. 2019:1-15. https://doi. org/10.1155/2019/7191935 